MAXIMIANO TRAPERO

LA MUUSICA EN EL ANTIGUO TEATRO DE NAVIDAD

\author{
Separata de la \\ REVISTA DE MUSICOLOGIA \\ Volumen $\mathrm{X}, \mathrm{n} .^{\circ} 2$ \\ Mayo-Agosto de 1987
}

MA D R I D

1987 


\title{
LA MÚSICA EN EL ANTIGUO TEATRO DE NAVIDAD
}

\author{
Maximiano TRAPERO
}

\begin{abstract}
Resumen: Investigamos 24 autos de Navidad pertenecientes al ciclo del "Officium Pastorum", fechados desde fines del siglo xV hasta la segunda mitad del siglo XVII: precisamente aquellos que reproducen un esquema escénico mínimo que sea "dramatización" del episodio evangélico del Nacimiento, excluyendo, por tanto, otras obras coetáneas sobre el mismo tema que no poseen una estructura dramática. Incluimos al final un indice de primeros versos de textos cantados.
\end{abstract}

Musica in ANTIQUo theatro de NATIVITATE

Summarium: XXIV dramata allegorica de Nativitate, id est "Officium Pastorum", exeunte decimo quinto usque ad finem decimi septimi saeculi composita, perspicimus, scilicet, quae delineationem scaenicam minimam addunt, exclusis ideo aliis scriptis coaetaneis de eodem themate structionem dramaticam non habentibus. Hoc in studio versuum indicem addimus.

\section{INTRODUCCIÓN}

LA falta de una bibliografía, siquiera mínima, sobre la música en el teatro primitivo nos obliga a ceñirnos a unos límites muy estrictos que queremos marcar de entrada.

Nos referiremos al teatro en lengua vulgar y no a los dramas litúrgicos en latín que le antecedieron y a los que sustituyeron, si bien no fue de una manera brusca, pues ambas manifestaciones debieron coexistir durante largo tiempo, aunque cada una de ellas reducida a unos espacios y a unos lugares determinados: el drama litúrgico en latín a las catedrales, los autos en romance a las iglesias de las zonas rurales.

Limitamos nuestro estudio al teatro en Castilla y en castellano, y descartamos las otras manifestaciones teatrales mucho más brillantes 
del este peninsular (Aragón, Cataluña, el Reino de Valencia), que respondían a otros modelos más acordes con el teatro europeo de la época, del cual se nos ha conservado un ejemplo precioso: $E l$ Misterio de Elche, entre otros muchos de menor relevancia.

Nos referimos sólo al teatro religioso y no al profano pues, si bien el origen del teatro en España está ligado indiscutiblemente a la liturgia religiosa y ése fue el único "teatro" existente en España en la Edad Media, con el Renacimiento nace el teatro profano, en un principio con unos personajes y unos esquemas idénticos a los religiosos (las Églogas de Encina, las Farsas y Églogas de Lucas Fernández, etc.), pero que pronto empieza a distanciarse evolucionando hasta las fórmulas del Barroco. Por el contrario, los autos religiosos siguieron fieles a unos esquemas tradicionales hasta su desaparición a principios del XvirI.

Dentro del teatro religioso nos ceñiremos con exclusividad al teatro de Navidad, y dentro de éste al ciclo del "Officium Pastorum", aunque necesariamente habremos de referimos, por contraste o por similitud, a los otros autos religiosos, como los del ciclo de la Pasión o, dentro de los de Navidad, a los autos de Reyes o a los Cantos de las Sibilas. Incluso dentro del ciclo del "Officium Pastorum" se decantan dos tipos de autos: los de esquemas realistas y estilo popular -el más viejo teatro castellano- y los de tipo alegórico-filosófico, que nacidos en el XVI desembocarán en los Autos Sacramentales del Barroco por un desplazamiento de la Navidad a la fiesta del Corpus Christi. Aquí nos referiremos con prioridad a los primeros, entre otras cosas porque son los más representativos del teatro español, los que siguen una línea uniforme y los que hicieron de la música un elemento fundamental de su carácter.

Por último, diremos que el tema de la música en el teatro lo abordaremos desde una perspectiva literario-teatral y no desde la estrictamente musicológica. La falta de una bibliografía específica sobre el tema, la falta de unos registros documentales suficientes de la música en el teatro religioso medieval y renacentista que permitan un estudio objetivo (los textos literarios que se cantaban si están en los autos, pero la música con la que se cantaban no) y, sobre todo, nuestra falta de competencia en tales cuestiones hacen que renunciemos a tal empresa y lo enfoquemos desde nuestra especialidad.

El corpus documental que tomamos como materia de investigación se compone de 24 autos de Navidad fechados desde fines del siglo XV (las Coplas de Vita Christi de Fr. Iñigo de Mendoza, de 1482, como primer texto) hasta la segunda mitad del XVII (el Auto Sacramental al Nacimiento de Antonio de Castilla, como último). No están en este corpus, naturalmente, todos los autos de Navidad que se escribieron, 
ni siquiera todos los conocidos ahora por ediciones más o menos modernas, pero es número suficiente para tenerlo por representativo del género. Entre los autores, los hay de nombre principal entre los que hicieron la historia del teatro y de la literatura española (Encina, Gil Vicente, Torres Naharro, Vélez de Guevara), los hay de nombre secundario (Gómez Manrique, Timoneda, Sánchez de Badajoz, López Yanguas) y los hay desconocidos totales para los manuales y diccionarios de literatura al uso (López Ranjel, Fernando Díaz, Godínez o Antonio de Castilla). Naturalmente cada obra es fruto del genio y calidad poética de su autor y el panorama resultante de ello muy diverso. Pero no es ése el aspecto que nos interesa aquí. Nos interesan todos y cada uno de ellos como ejemplos teatrales dentro de los cuales la música va a jugar un papel determinado.

Por otra parte, excluimos de la lista y de este estudio las obras que, aun siendo pastoriles y de Navidad (caso de la Égloga I de Encina "representada en la noche de la natividad de nuestro Salvador, adonde se introducen dos pastores, uno llamado Juan y otro Mateo", como dice el propio autor en la introducción), están lejos de reproducir un esquema escénico mínimo que sea "dramatización" del episodio evangélico del Nacimiento (S. Luc., cap. 2, vv. 8-20) o aquellas otras que no pasan de ser una colección de textos (villancicos, coplas, canciones, romances) dedicados al Niño Jesús la noche del Nacimiento (numerosísimos en la literatura renacentista y barroca), incluso con personajes pastores y "estilo pastoril", pero que no poseen una estructura dramática; caso, por ejemplo, de los romances Al Nacimiento de Cristo, de Lope de Vega, ' de las Coplas al Nacimiento, de Fr. Ambrosio Montesino, ${ }^{2}$ de los Villancicos para cantar de la Natividad de N.S.J. de Esteban Zafra (Toledo, 1545) o del Libro de romances y coplas del Carmelo de Valladolid. ${ }^{3}$

\section{Primeras manifestaciones musicales en el teatro Religioso en LENGUA VULGAR}

Está muy extendida la idea de que el primer dramaturgo español es Juan del Encina y de que, en consecuencia, la aparición de un villancico cantado al final de las obras es una costumbre inaugurada por él. Y si a lo primero hay que poner algunos reparos a lo segundo

I Obras Escogidas, II, Madrid, Aguilar, 19644, pp. 111 y 230-233.

2 B.A.E., XXXV, 1950, pp. 401-466.

3 Ed. de Víctor García de la Concha y Ana M. Alvarez Pellitero, Salamanca, Consejo General de Castilla y León, 1982. 
hay que ponérserlos del todo. Ya hemos expuesto en otra parte ${ }^{4}$ nuestra idea de que Juan del Encina, al menos en el teatro religioso, que es el origen del teatro en Castilla, no inauguró nada, que fue uno más, aunque eso sí, de los de mayor nombre y de los primeros en tenerlo, en la cadena de una tradición que hunde sus raíces en los oscuros años de la Edad Media y que, con pocas variantes, llega casi intacta hasta el siglo XVII, para desembocar en una nueva corriente, nacida de la anterior, de signo totalmente alegórico y que llenó una de las páginas más brillantes de la historia del teatro español; nos referimos a los Autos Sacramentales. Eso por lo que se refiere a las obras de autor conocido. Porque la tradición estaba también en las manos y en la boca del pueblo anónimo, y éste ha sabido conservarla hasta hoy mismo. No otra cosa son, con toda la diversidad y ramas que ellas representan, con toda la dispersión geográfica y con sus historias particulares, las pastoradas leonesas, las pastorales vascas, els pastorets catalanes, los ofrecimientos y villancicos representados que perviven por muchos lugares de España, las posadas mejicanas, los pesebres argentinos, los autos de Reyes, el Misterio de Elche, las representaciones y dramatizaciones litúrgicas sobre la Pasión (los monumentos) y la Resurrección (los encuentros), etc., etc.

Encina inauguró una corriente del teatro renacentista, la égloga pastoril, que tuvo inmediatos y lejanos continuadores, pero en lo que se refiere al teatro religioso tiene, a su vez, antecedentes bien definidos. Es más, Encina empezó su producción dramática con obras de tipo religioso bien representativas de los dos ciclos medievales: la Navidad y la Pasión. De las 8 Églogas de que consta su primera producción dramática, contenida en su Cancionero de 1496, las 4 primeras son religiosas: las dos primeras del ciclo de Navidad y las dos siguientes del ciclo de la Pasión (una de la Pasión y otra de la Resurrección). ${ }^{5}$

En cuanto a la inclusión de la música en el teatro, Encina no tiene nada de innovador. Otra cosa será que, dada su condición de gran poeta y exquisito músico, las obras que de Encina se conservan sobresalgan artísticamente de las'de sus contemporáneos (y continuadores). Y a decir verdad, Encina es menos músico en su teatro religioso que la media de los otros autores de autos de Navidad. Encina se limita casi con exclusividad al villancico epilogal o "de

4 "Tradicionalismo en el primitivo teatro castellano: Los autos del ciclo del 'Officium Pastorum'", en Actas del Congreso Internacional sobre Calderón y el teatro español del Siglo de Oro, Madrid, C.S.I.C., 1981, 1715-1730.

5 Encina llama a todas sus obras "Eglogas", excepto a la 3, a la 4 y a la 10 que las llama "Representaciones", y a la 13 "Auto". 
cabo", mientras que los otros autores (la gran mayoría), además del villancico final, intercalan otras piezas musicales en medio de sus obras. De entre las 14 Églogas del salmantino 3 no tienen música ninguna (las 1,9 y 13) y sólo dos intercalan un villancico en la mitad de la obra (las 8 y 14); las demás siguen fielmente el modelo más común que consiste en acabar la representación con un canto conjun. to de todos los personajes al salir de escena.

El modelo común es, efectivamente, que la representación acabe con música. Pero ¿qué tipo de música? ¿Cantan sólo o también bailan? ¿De qué instrumentos se sirven los cantores? ¿Se canta siempre un mismo modelo textual y estrófico? Más aún: ¿La música se da sólo al final o también en el interior del auto? ¿En qué proporción? ¿Y en qué momentos del interior? En definitiva: ¿qué función cumple la música en el teatro religioso?

Nos referimos aquí, claro está, a la música incorporada al cuerpo de las obras y no a la música que se hacía entre los distintos actos de las comedias o como comienzo y colofón de la fiesta teatral, esa fiesta "total" que llegó a ser el espectáculo de los corrales de comedias durante todo el siglo XVII, en donde la propia comedia se vio envuelta entre bailes, entremeses, cantos, loas, jácaras, mojigangas y músicas y danzas de todo tipo.

Pretender fijar una fecha y un texto como iniciadores de la incorporación de la música en el teatro resultará del todo vano, pues la música está en el origen mismo del teatro: música y danza son elementos constitutivos del teatro (hasta tanto que algunas civilizaciones primitivas los tienen como único lenguaje teatral). $Y$ por lo que respecta al origen del teatro en España hay que decir que no tiene otro que la música: una forma musical mínima -los tropos- que con el tiempo se irá desarrollando hasta convertirse en auténticos dramas litúrgicos. Primero en las representaciones eclesiásticas de la liturgia de las grandes solemnidades, de forma muy simple, en donde cada oficiante cantaba (e interpretaba) la secuencia o el texto correspondiente a un personaje: un simple diálogo de secuencias sucesivas interpretadas por distintas voces; después ampliándose hasta conseguir secuencias y escenas más complejas en donde ya no sólo intervenía la voz sino también la acción. Pero en todo ello tomando como elemento sustentador la música y el canto.

En España, como en el resto de Europa, los tropos se fijaron fundamentalmente en dos fiestas muy concretas de la liturgia eclesiástica: la Navidad y la Resurrección. El desarrollo de estos tropos dio lugar a auténticos dramas cantados en latín, de los que muy pronto derivaron en Castilla obras religiosas en lengua romance ligadas, de la misma forma que los tropos, a los ciclos de la Navidad y de la Pasión, 
pero liberadas ya de la fidelidad al texto litúrgico. Entonces el texto hablado predominó absolutamente sobre el texto cantado porque habían cambiado las funciones: el drama en latín era una celebración, el auto en romance una ejemplificación. Pero los textos cantados nunca desaparecieron del todo. De tal forma, que la música de nuestro teatro antiguo no fue una incorporación efectuada por los dramaturgos del XV y XVI, sino restos y pervivencias de lo que en la Edad Media no fue más que música.

La música debió estar ya en el primer texto dramático castellano conservado, el Auto de los Reyes Magos, cerrando la obra y como colofón a la escena que falta en el manuscrito conservado (la adoración al Niño Jesús y la despedida de los Reyes). Así lo supone Adolfo Salazar ${ }^{6}$ y así lo propone Lázaro Carreter en su edición del Auto: "A oscuras aún, se oye la primera estrofa de un villancico popular, acompañada por instrumentos rústicos" (p. 106).

Y desde luego, la música está también en las obras inmediatamente posteriores al Auto de los Reyes Magos, aunque en ese inmediato haya que salvar un vacío de casi tres siglos para llegar a los primeros dramaturgos de la segunda mitad del XV. Está en la Representación del Nacimiento de Gómez Manrique (entre 1467 y 1481), está en las escenas del Nacimiento de la Vita Christi de Fr. Ínigo de Mendoza (1482) (escenas a las que consideramos auténtico teatro, aunque la obra general no lo sea), está en el anónimo Auto de la Huida a Egipto (entre 1446 y 1512) y está, por supuesto, en las Églogas de Encina. Y después de él en todos los autos de Navidad de los siglos XVI y XVII.

\section{La música en el teatro del "Officium Pastorum"}

Digamos que la presencia de la música en el teatro religioso de Navidad es una constante que responde, más que a la iniciativa personal de cada autor, a la pervivencia de una costumbre muy bien asentada en la tradición, fielmente aceptada y recreada una y cien veces por los dramaturgos de los siglos XV, XVI y XVII. De la misma forma que es constante, recreado una y cien veces, el esquema escénico del auto o ese típico lenguaje sayagués que se pone en boca de los pastores. Es verdad que los autos del "Officium Pastorum" se prestan mejor para la presencia de la música en ellos que otros tipos de autos religiosos y mucho más que el teatro profano, en general. Al

6 Cit. por R. Pérez Sierra, "La música en nuestro teatro clásico y en el teatro lírico de Calderón", en III Jormadas de Teatro Clásico Español (Almagro, 1980), Madrid, Ministerio de Cultura, 1980 , p. 258. 
fin y al cabo, el relato contenido en los autos navideños conlleva la acción musical: los ángeles bajan del cielo cantando la Buena Nueva, los pastores cantan y bailan y muestran su regocijo ante el Portal, es preceptiva la referencia a los múltiples instrumentos musicales pastoriles, etc. El hecho es que los autos de Navidad pueden ser tenidos como la muestra más representativa y sobresaliente del teatro antiguo en que la música tiene una presencia muy significativa.

De las 24 obras del "Officium Pastorum" que hemos catalogado y estudiado, como muestra representativa del género (4 del siglo XV, 13 del XVI y 7 del XVII), sólo una no contiene música alguna, precisamente una de Encina, la Égloga 9 "De las grandes lluvias". Todas las demás contienen al menos una intervención musicada (un cántico, una danza, una pieza instrumental, o las tres cosas a la vez). Y no son pocas las obras que tienen 3, 4 y hasta más números musicales. Ejemplos preciosos de éstas son, por ejemplo, el Auto pastoril castellano de Gil Vicente, la Farsa a honor y reverencia del glorioso Nascimiento de López Ranjel, la Danza del Santisimo Nacimiento de Suárez de Robles, la Obra del Santísimo Nacimiento de Bartolomé Aparicio o el Auto do Nascimiento del madeirense Baltasar Dias, quien escribe su obra en portugués pero reserva el castellano para los diálogos de los pastores, al estilo sayagués, tan característico del teatro pastoril renacentista. $Y$ ejemplos en el lado opuesto que contienen un solo número musical pueden ser las Coplas de la Vita Christi de Fr. Iñigo de Mendoza, la Egloga 2 que comienza "Dios mantenga" de Encina, la Égloga o Farsa del Nacimiento de Lucas Fernández o la Farsa de la Natividad de Sánchez de Badajoz, aunque en éste sólo se propone cantar un villancico al final sin que efectivamente se cante. Entre ambos extremos está el mayor número de obras con dos, tres o cuatro números musicales cada una, como puede verse en el gráfico siguiente.

Una excepción merece ser destacada: la de la Comedia a lo pastoril para la noche de Navidad (1550), una obra anónima de tipo alegórico que merecería un estudio particular, pues en ella hay nada menos que 20 villancicos cantados.

En el gráfico que sigue puede verse el panorama de la música en el teatro del "Officium Pastorum" con indicación de las tres modalidades que en ellos aparecen: el canto, el baile y el baile cantado. Se da por supuesto el acompañamiento instrumental en los tres casos. Sólo en dos ocasiones, al final de las obras de Vélez de Guevara y de Godínez $A$, se sustituye el canto por sendas intervenciones instrumentales sin voz y sin texto. Hemos de hacer constar, además, que en el gráfico sólo se han anotado las intervenciones musicales reales, es decir, las inequívocamente señaladas en el texto por los propios autores. A ellas habría que sumar, posiblemente, otras no especificadas por el autor 


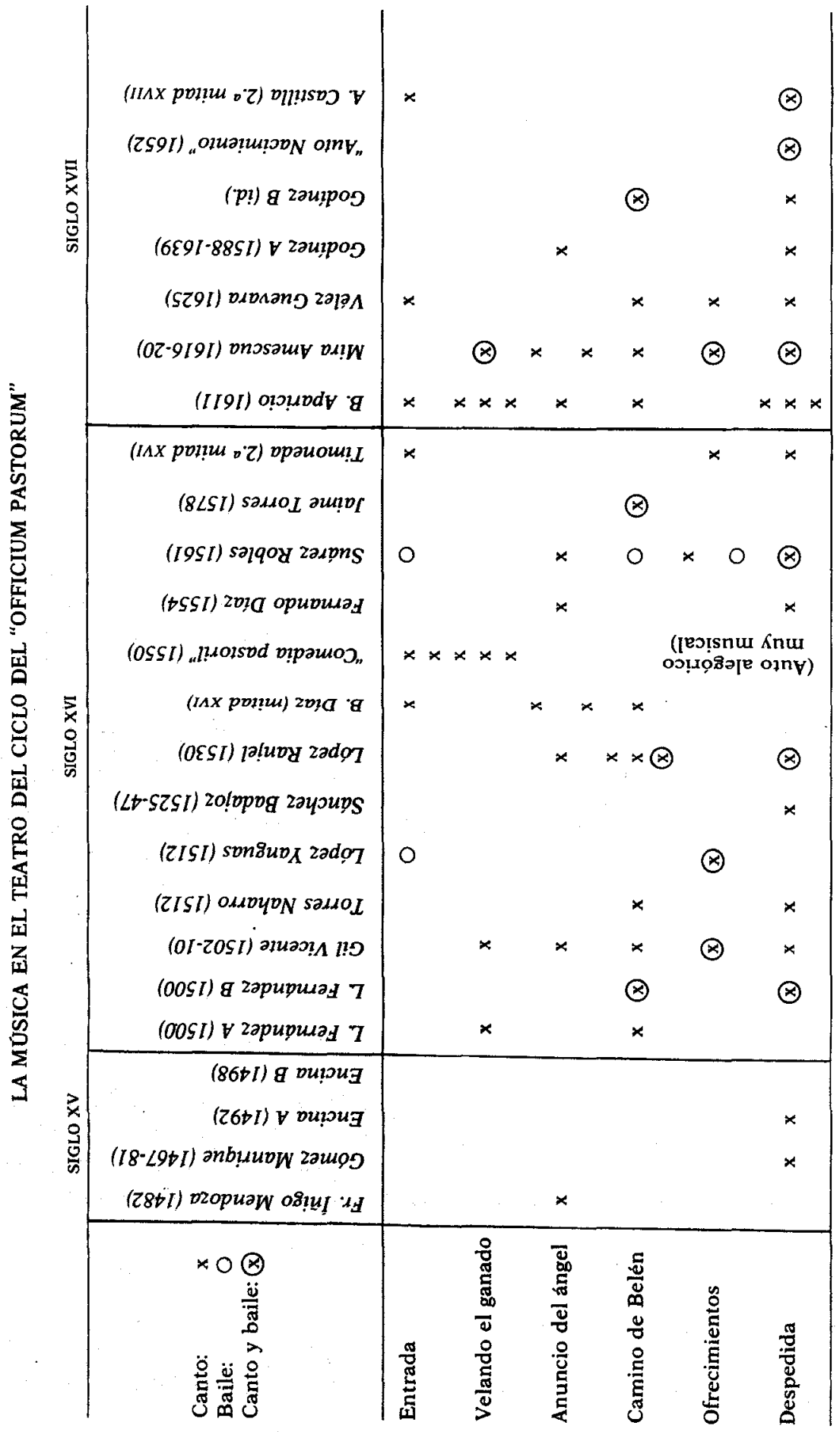


pero que poseen las características de todo texto cantado, como es, por ejemplo, el anuncio del Ángel en la Égloga IX (que sí es auto de Navidad pastoril) de Encina:

Pastores, no ayáys temor, que os anuncio gran plazer.

Sabed que quiso nacer esta noche el Salvador redentor en la ciudad de David.

(Encina B, vv. 193-198)

\section{La FUNCIÓN ESCÉNICA DE LA MÚSICA}

No vamos a negar que la forma musical más característica es el villancico epilogal que remata la obra con la salida de escena de todos los personajes cantando, y a veces, bailando y tocando los instrumentos. Esta fórmula es común tanto en el teatro religioso como en el profano, pero no es la única. No lo es en el teatro profano y mucho menos lo es en el religioso. Lo importante es que; dentro del teatro navideño, la música y lo musical aparecen no indiscriminadamente, a la libre voluntad de cada autor, sino sometidos a unos esquemas generales que responden a las propias características del género.

Ya hemos dicho en otra parte (art. cit.) que los autos de Navidad, en su gran mayoria, siguen muy de cerca un mismo esquema argumental y escénico, basado en el relato evangélico que quieren ejemplificar y en los modos dramáticos heredados por la tradición. No de otra forma podía ser un teatro repetitivo, que nace para ser representado cada año entre las gentes sencillas y crédulas, según un modelo que llegó incluso a los títulos de no pocas obras: "al modo y estilo pastoril y castellano".

En este modelo dramático, como denominador común, se suceden, con las variantes e improntas propias de cada autor, las siguientes principales escenas:

a) Entrada en escena

b) Velando el ganado

c) Anuncio del ángel

d) Camino de Belén

e) Adoración y ofrecimiento ante el Portal

f) Despedida y salida de escena

Pues bien, la música y las partes cantadas se van a centrar precisamente alrededor de estas escenas. Sólo los autos de tipo alegórico (por 
ejemplo, la Farsa de la Natividad de Sánchez de Badajoz o el Diálogo del Nascimiento de Torres Naharro) se apartan de este modelo "pastoril y castellano" careciendo totalmente de música o, según el modelo general de la época, conteniendo sólo un villancico final.

La música en los autos de Navidad no es, pues, un simple aditamento que se justifique como ornato de la acción, cambio de ritmo de la recitación, entretiempo para los cambios de escena, recurso para agilizar la trama o simple componente del espectáculo total que el teatro fue en el Barroco. La música cumple en el teatro de Navidad un papel estructural.

\section{a) Entrada en escena}

Los pastores entran en escena uno a uno, sucesivamente, o en grupo, dispuestos a la representación. Lo segundo es lo más común para el canto, pero no es infrecuente la fórmula primera en la que cada personaje aparece en escena tocando un instrumento y cantando su propio texto:

Llega Mingo Sabido, tañendo una gaita y dize:

iLas gaitas, guitarras, rabés repiquemos

y las churumbelas muy huerte tangamos!

iCordojos, renzillas de nos despidamos

y brincos, corcovos y saltos echemos!

iLos hatos y migas y burras dejemos,

quitemos las tristes capillas de nos!

iQue nuevas hay, nuevas, que es nacido Dios!

iGil Pata, Gil Pata, ven, ven y bailemos!

(López Yanguas, Egloga de la Natividad, vv. 1-8)

A veces, la acción musical se contiene entre las acotaciones del autor al comienzo de la escena, como ésta que nos ilustra con minuciosidad sobre las representaciones en las iglesias:

Han de salir los pastores en dos hileras repartidos, delante dellos el que tañe el salterio o tamborino; al son irán danzando hasta en medio de la iglesia, y allí harán algunos lazos, y tras los pastores irán los ángeles con los ciriales; y si hubiere aparejo, ocho ángeles que lleven el palio del Santísimo Sacramento, y debajo irá Nuestra Señora y San Josef, y llegarán hasta las gradas del altar mayor, y allí estará una cuna al modo de pesebre, y allí pondrán al Niño Jesús; y de rodillas, Nuestra Señora y San Josef, puestas las manos como contemplando; los ángeles repartidos a un lado y a otro, los rostros vueltos unos a otros y mirando hacia el Niño; y estando desta manera, acabarán los pastores de danzar, 
y luego saldrá un Ángel al púlpito y dirá lo siguiente, y los pastores, oyendo la voz, mostrarán espantarse mirando a una y otra parte.

(P. Suárez de Robles, Danza del S. Nacimiento, pp. 51-52)

Esta fórmula de Suárez Robles es idéntica a la que pervive hoy en las pastoradas leonesas: Finalizada la misa del gallo y permaneciendo todos los fieles en la iglesia, entran los pastores y demás personajes en dos filas, ataviados con sus respectivas vestimentas, los pastores llevando una cordera bellamente adornada para ofrecerla a la Virgen, hasta colocarse en el lugar destinado para la representación. En el trayecto cantan y bailan villancicos propios de la representación.

\section{b) Velando el ganado}

Desde la entrada en escena hasta el anuncio del Ángel, la tradición teatral navideña hace común una escena intermedia en la que los pastores velan su ganado, entreteniéndose mientras tanto en juegos, disputas o relatos alegóricos al Nacimiento, advierten presagios extraños que les hacen hablar de una "noche extraordinaria", protestan del frío y de los pocos pastos y encienden el fuego donde calentarse y comer las migas. En estos momentos algunos cantan para entretenerse:

iRiedro, riedro! iVaya el ceño!

Aborrir quiero el pesar.

Començaré de cantar

mientras me debroca el sueño.

\section{Canta Gil}

"Menga Gil me quita el sueño, que ño duermo".

(Gil Vicente, Auto pastoril, vv. 19-24)

Y otros bailan para calentarse:

La zampoña y tamboril tocad, porque hemos de her una danza, y de essa suerte podrá ser que calentemos.

(Mira de Amescua, Auto del nacimiento, p. 124) 
c) Anuncio del Ángel

Uno de los textos cantados más unánimemente fijado en la tradición teatral es el anuncio del Ángel. En la mayoría de las obras se especifica que es cantado:

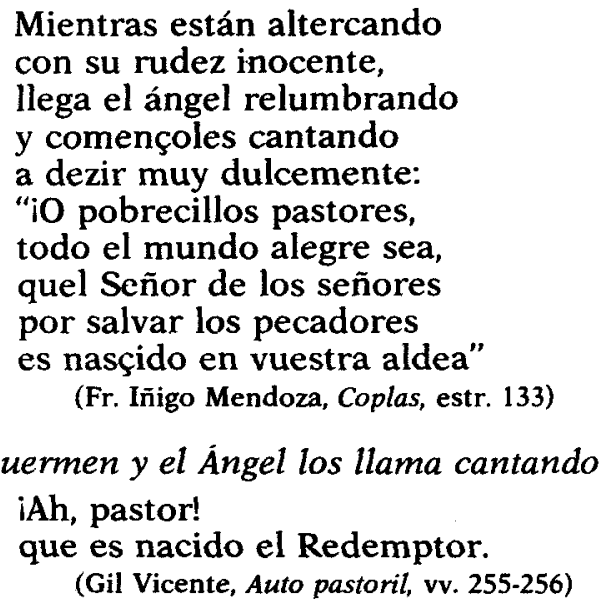

Y en las que no hay acotación alguna por parte del autor hay que darlo por supuesto, por la forma estrófica elegida, bien diferenciada del resto y perfectamente configurada para la música (como en Encina, B, vv. 193-208).

En las versiones modernas de las pastoradas leonesas es también el anuncio del Ángel uno de los números musicales por excelencia. Interesa decir aquí que la música del anuncio de las pastoradas es una contrafactura de la melodía del Gloria de la Misa De Angelis, pero modificando el orden de la frase musical, adaptándola al compás ternario y a la estructura rítmica del verso octosilábico del texto cantado, como puso en evidencia L. Siemens en su estudio de las partes cantadas de la pastorada.?

\section{d) Camino de Belén}

Una vez convencidos de la Buena Nueva, los pastores deciden ir a Belén a ver al Niño y ofrecerle sus dones. La alegría que entonces llevan no pueden expresarla mejor que con cantos, músicas y bailes. Y así lo dicen ellos mismos una y otra vez, casi de forma unánime:

7 M. TRAPERO y L. SIEMENS, La pastorada leonesa: Una pervivencia del teatro medieval, Madrid, S.E.M., 1982, p. 325. 
Salen para el pesebre cantando

Aburramos la majada, y todos con deboción vamos ver aquel garzón.

Veremos aquel niñito d'agora rezién ñacido.

Asmo que es el prometido, nuestro Mexía bendito. Cantemos a boz en grito:

Con hemencia y devoción veremos aquel garzón.

(Gil Vicente, Auto pastoril, vv. 283-292)

\section{Cantiga}

Tomemos todos pastores gran gasajo y alegría con el hijo de María.

Esta donzela real quiso parir en Bethlem nuestro gozo y nuestro bien la clara luz divinal:

pues por la gente humanal parió la Virgen María tomemos grande alegría.

Tomen grande regozijo los ángeles de Dios Padre, con la madre de tal Hijo pues quer por nós nascer quiso por quitarnos la gonía tomemos grande alegría.

(B. Dias, Auto do Nascimiento, pp. 193-194)

En la Danza de Suárez de Robles no cantan pero sí bailan:

Aquí hacen un lazo de danza y van danzando para donde está el Nacimiento, y antes que paren, hacen allí delante el mismo lazo (p. 56).

En la Farsa de López Ranjel se contienen en esta escena no uno sino tres villancicos, cada cual más bello. Éstos son sus estribillos respectivos:

(Primero)

Vamos todos en buen hora y diciendo todos este apellido: 
buen estrena, buen nascido

chiquito nos es nacido,

nazca, nazca norabuena.

\section{(Segundo)}

Hoy parió la luz del día, hoy parió;

gran gasajo y alegría

tengo yo.

\section{(Tercero)}

Huyhá, huyhó, pues nasció el que el mundo redimió.

Por último, en la Lucha alegórica de Jaime Torres se contiene otro villancico que, al acabar aquí la representación (faltan el ofrecimiento y la despedida), sirve a la vez de villancico epilogal:

Todos, pues, nos compongamos, para allá partir con priesa; pero, porque presto vamos, tomemos por la traviesa del cerro donde apriscamos.

Y pues el cielo alegrando se está, según se demuestra, vámonos todos bailando; y tú, Antón, el baile adiestra, una canción entonando.

[...]

\section{Canción}

iHola, hau, carillos!

Pues a Dios tenemos, dejad los corrillos y venid, bailemos. (pp. 76.77)

e) Adoración y Ofrecimiento al Niño

Los pastores ante el Portal ofrecen sus dones al Niño y lo adoran diciéndole maravillas. Para ambas acciones se recurre en los autos con mucha frecuencia al canto, al baile o a ambas cosas a la vez. Una fórmula muy repetida es el ofrecimiento individual y sucesivo de cada pastor con un estribillo intermedio entonado por todos, como en la Danza de Suárez de Robles: 
Aquí sale Antón danzando, y desque ha hecho alguna mudanza, queda hincado de rodillas y dice:

Adórote mi hàcedor, de pastores mayoral; adórote Redentor, pues quisiste por mi amor, nacer hoy en un portal.

[...]

Aquí puede ofrecer un sonajero o otra alguna cosa; y luego tocarán el instrumento, al son del cual se levantará Antón danzando, y juntamente saldrá Rebanado, y a un mesmo son pueden danzar ambos: el uno hasta ponerse en su lugar y el otro hasta ponerse en el lugar adonde Antón se hincó de rodillas; y pararán iguales. Y lo mismo harán los demás por el mismo término p. 58).

o en el Auto del Nacimiento de Vélez de Guevara:

GINES: Haga, pues, su reverencia cada qual, y presumiendo de que a Dios hablando está.

GIL: Llegue Llorente primero y llegaremos después assí hablar por su orden, Ginés. (p. 86)

Danzas colectivas organizan los pastores del Auto del Nacimiento de Mira de Amescua:

Regocijemos la fiesta.

¿Qué hacemos que no bailamos?

Un cruzado concertar podemos, que es lo mejor.

$$
\text { (p. 128) }
$$

y los de la Farsa de López Ranjel:

BenIto: Pues vamos, no nos tardemos; cata que estás espacioso.

JUAN: Vamos luego. ¿Qué haremos?

BRAS: Di, Juan, icómo le diremos a este rey glorioso?

JUAN: Un cantar sea gracioso.

DOMINGo: $Y$ también bailar tenemos, y canticando diremos.... (v่v. 445-452) 
Episodio singularísimo por su interés para la música en el teatro, y ejemplo precioso de lo que aquí estamos exponiendo, es el que se contiene en el final de la Égloga de la Natividad de López Yanguas, en donde ya no es el autor quien hace las acotaciones sobre las acciones en escena sino los propios personajes en diálogo directo quienes hablan y se preparan para el canto y el baile que van a realizar como ofrecimiento y adoración al Niño Dios:

MINGo: $\quad$ Si sabes de mosica alguna cosilla, cantemos en grita aquí todos yuntos.

GIL PATA: iTomá qué pregunta! Sé todos los puntos

MINGo: $\quad$ Y tú, Pero Pança, cen tono de villa sabrás chillar algo aquí, si te yuntas?

Pero Pança: iMira qué donoso, qué necias preguntas!

Sé todos los tonos con su subidilla.

Y tú, Benitillo, charásnos ayuda con voz agudilla, bailando la dança?

BENITO: Yo, par diez, que cante diapente y mudanza $\mathrm{y}$ al canto de guérgano yo le saguda octavas, novenas, con voz bien aguda, ipor alto los pies, que habrás gasajado!, y cortos y breves, tú pierde cuidado, con máxima y longa yo hago que acuda.

GIL PATA: Chápemosle ahora sonetos, canciones, y ande la trisca subida son saltos, que suenen las vozes por cima los altos.

Pero Pança: Parece, Gil Pata, que en orden te pones.

Tú mira, carillo, que no desentones, Aguarda que en falta ninguna caigamos. A este divino moçuelo sirvamos, que no coge cosa sino coraçones.

Mingo: $\quad$ Pues ande la dança aquí al rededor, trabémonos todos muy bien de las manos con gestos alegres, jocundos y ufanos comiençe la música con dulçe primor. Y lleva, Gil Pata, si quies, el tenor; tú frísale el tripe, Benito, las martas; tú di, Pero Pança, requintas y cuartas que yo diré luego la cuentra mayor.

\section{Villancico}

iAh, Gil Pata! ¿Qué es, carillo?

Hamos aquí una dança, 
por servir este chiquillo.

Demos çapatetas, saltos,

cada cual con su respingo.

Haz una vuelta tú, Mingo,

vayan los corcovos altos.

¿Passo, Passo! ¿Qué es, carillo?

Ten crianza,

no desconciertes la dança,

por servir a este chiquillo.

Ande en compás el bailar

con chapadas castañetas;

vayan las voces perhetas,

que suene bien el cantar.

Digo, digo, da gritillo

con mudança.

Ande derecha la dança

por amor de este chiquillo.

Da acá toste esse caldero,

sopemos huerte las migas,

hinchamos estas barrigas.

Sopa tú, Mingo, primero;

traga, traga, Benitillo

con tempraça.

Demos ya fin a la dança, tornemos al ganadillo.

El texto de Yanguas resume como ninguno los elementos todos que intervienen en la música del teatro de Navidad: el canto, los instrumentos y la danza: todo conjuntado para ofrecer la música total que se sobrepone a un texto literario al servicio de la idea musical. Un texto que, hasta en el lenguaje, está plagado de tecnicismos musicales referidos a cada una de las tres manifestaciones individuales, poniendo bien en claro que los personajes lo ejecutan efectivamente sobre el escenario y no sólo lo mencionan. A saber:

Canto. Mingo propone cantar "en grita" (v. 449), es decir, a voz en grito. Gil Pata presume de saber "todos los puntos de sol, fa, mi, re" (v. 451), lo mismo que Pero Pança de saber "todos los tonos" (v. 455). Benito sabe distinguir "octavas" de "novenas" (v. 460), "breves" (v. 462) de "longas" (v. 463), y hasta es capaz de cantar el "diapente" (v. 458), es decir, el quinto intervalo, que consta de tres tonos y de un semitono menor (Dicc. Aut.). Lo que está proponiendo Mingo es un coro concertado de 4 voces, un "canto de órgano" (v. 459), ${ }^{8}$ en que cada uno hará

"Interpretación errónea de este "canto de órgano" es la que ofrece el editor de la Egloga de Yanguas que identifica "güerfano" con "el nombre de algún instrumento 
una voz determinada; un canto polifónico, en definitiva: el tenor será Gil Pata (v. 476), el bajo el propio Mingo ("cuentra mayor", v. 479), Pero Pança hará las "requintas y cuartas" (v. 478) y Benito, el de la voz "agudilla" (v. 457), "frisará al tripe las martas" (v. 477), es decir, hará las voces más agudas. ${ }^{9}$ En fin, todo bien armonizado, sin caer en falta alguna (v. 469), con voces perfectas que hagan sonar "bien el cantar" (v. 495), cantando de todo: "sonetos" o "canciones" (v. 464), que bien lo merece ese "divino moçuelo" (v. 470) al que van a ir a adorar.

Instrumentos: Más dificil interpretación, por lo escueto de las citas, tienen los nombres de los instrumentos con que los pastores se quieren acompañar en sus cánticos y danzas. Sólo las castañuelas ("castañetas", v. 493) son aquí instrumento seguro. Luego cabe que ese problemático "martas" (v. 477) sea un pandero ('de piel de animal' dice el Dicc. de Covarrubias) y que el "tripe" sea un instrumento de cuerda en vez de una modalidad de voz. Un baile al son de castañuelas y pandero sería lo más acorde con la cultura tradicional pastoril.

Danza. No puede haber música mejor expresada ni alegría mejor manifestada que "bailando una dança" (v. 457), con "çapatetas y saltos" (v. 485), cada cual con su "respingo" (salto violento y brioso, v. 486) y con muy altos "corcovos" (saltos altos y encorvados, v. 488); en fin, una danza que tenga sus "mudanzas" (v. 497) y que empiece con un lazo de manos bien trabadas (v. 473) en muestra de gesto alegre, jocundo y ufano.

\title{
f) Despedida y salida de escena
}

Algunos de los villancicos más famosos contenidos en el teatro español corresponden justamente a esta escena de los autos de Navidad. Así, por ejemplo, el bellísimo de la Representación de Gómez Manrique:

\author{
Callaos, Señor, \\ nuestro Redentor,
}

musical, quizá deformación humorística de "organo". Pero -sigue diciendo González Ollé- "canto de guierfano" pudiera referirse también al canto de los niños (el texto menciona 'voz aguda') que, por su condición de huérfanos precisamente eran recogidos en alguna institución benéfica, en la que desempeñaban oficio de cantores; recuérdese -dice el editor para rematar interpretación tan pintoresca- la costumbre de que estos niños acompañasen corporativamente los entierros, en especial de sus protectores".

9 Un problema de interpretación plantea este verso 477: puede referirse a un instrumento musical o a una modalidad de voz. El editor F. González Ollé plantea dos alternativas interpretativas: "frisar las martas" como tocar las cuerdas de tripa de un instrumento musical, o "frisar el tripe" como cantar la voz más aguda con ayuda de un instrumento de cuerda de animal. 
que vuestro dolor durará poquito.

(p. 115)

- el más famoso y bello aún de Gil Vicente del Auto de la Sibila Casandra, que aunque no sea pastoril sí es auto de Navidad:

Muy graciosa es.la donzella, icómo es bella y hermosa!

Digas tú, el marinero que en las naves bivías, si la nave o la vela o la estrella es tan bella. (vv. 468-473)

La fidelidad al relato evangélico es total en este punto: "Los pastores se volvieron glorificando y alabando a Dios por todo lo que habían visto y oído" (Lucas, 2.20). Los pastores, después de ofrecer sus dones y de adorar al Niño, se despiden del público y marchan a sus hatos cantando las maravillas que han visto. Éste es el final que se repite apenas sin variación en todos los autos. Los que no contienen el texto que los pastores cantan, al menos lo referencian. Como en la Farsa de la Natividad de Sánchez de Badajoz:

$$
\begin{aligned}
& \text { Ea, quedar } \\
& \text { que me llaman a cantar, } \\
& \text { quien no quisier perdonar } \\
& \text { y digos en fin, en fin, } \\
& \text { que se quede por ruin. } \\
& \text { (vv. 1926-1930) }
\end{aligned}
$$

Y los autos que han acabado en alguna escena anterior, sirvió aquélla de despedida (como en los de L. Fernández A, Yanguas y J. Torres, ya referenciados).

Pero lo ordinario es que se exprese textualmente esa intención de despedida en este momento y que se utilice con ese fin un canto a propósito. Como en la Danza de Suárez de Robles:

ANTON: Digamos un cantarcillo

en loor deste zagal, y pues quita nuestro mal, danzaremos un poquillo alrededor deste portal. 
Rebanado: Pues empiézalo tú, Antón, que todos te seguiremos; y en acabando iremos, en buena conversación a do el ganado tenemos.

Aqui cantan los pastores este villancico...

Allá en Belén nace nuestro Dios, nace de María para bien de nos... (vv. 282-295)

O en la Obra de B. Aparicio:

Despidámonos cantando
con un cantar excelente.

Canción

Pues habemos adorado a este santo mozuelo en pago nos dará el cielo...

Y a continuación le siguen otras dos despedidas, también cantadas dirigidas principalmente a la Virgen. $\mathrm{O}$, en otros autos, dejando bien de manifiesto el carácter "teatral" de la actuación ante un público al que se pide perdón por los errores de la representación, como en el Auto B del Doctor Godínez:

Perdonad noble Senado, muchos defectos forçosos, por las angustias del tiempo, que ha sido ocupado y corto, y Dios os dé buenas Pascuas que os celebremos devotos.

(pp. 110-111)

Pero donde mejor se expresa la condición de "pregoneros" que los pastores se atribuyen de lo que han "visto y oído" es en la despedida que Lucas Fernández pone en su Auto o Farsa, en un villancico delicadísimo:

-Dezid, los pastores, qué venís de ver con tanto plazer. 
-Vimos a María muy noble donzella, que ansí reluzía como clara estrella, la más linda y bella que fué ni ha de ser, ni s'espera ver. (vv. 586-595)

\title{
5. LOS TEXTOS CANTADOS
}

De todos los metros utilizados en el teatro navideño el preferido para el canto es, sin duda, el villancico. Naturalmente hablamos del "villancico" como cantar 'a lo villano', o sea, como canción de inspiración y estilo popular, y no del "villancico" con el sentido de "canción de navidad' que adquirirá más tarde (justamente por el uso abundantísimo que tuvo en canciones de tema navideño), aunque curiosamente aquí, en nuestro tema, se unen los dos sentidos.

La multiplicidad de formas estróficas (número de versos, rimas diversas, estribillos de más o menos versos, distinta media de los versos, combinaciones de rima variada, etc.) que llegó a adquirir el villancico se refleja también en el teatro navideño. El más abundante es el modelo clásico: $a b b$ cddccbb. Como en este ejemplo de Lucas Fernández perteneciente a su Auto o Farsa:

\author{
Gran deporte y gran conorte \\ devemos todos tener \\ pues Christo quiso nascer. \\ Devémonos gasajar \\ pues qu'es Dios de Dios venido. \\ Hombre y Dios no confundido, \\ Dios y Hombre singular. \\ Todos, todos a cantar, \\ todos a tomar plazer, \\ pues Christo quiso nascer.
}

(vv. 541-550)

Es decir, una composición con estribillo y copla. "La cabeza -como dice Juan Díaz Rénfigo en su Arte Poética Española (1592)- es una copla de dos o tres versos, que es como glosa de la sentencia que se compone en la cabeza. La cabeza del villancico ha de llevar algún dicho agudo y sentencioso, y puede ser de versos enteros o de versos enteros quebrados." 
Efectivamente, los versos de pie quebrado abundarán sobremanera en los villancicos, modelo en el que Encina es maestro indiscutible. Y de pie quebrado es el villancico que el salmantino pone al final de su Égloga 2, que comienza "Dios mantenga":

Gran gasajo siento yo.

iHuy ho!

Yo también, soncas que ha.

iHuy ha!

Pues aquél que nos crió,

por salvarnos nació ya.

iHuy ha! iHuy ho!

que aquesta noche nació.

(vv. 181-188)

Villancico éste de Encina que fue imitadísimo por los dramaturgos posteriores, como por López Ranjel en estos dos ejemplos siguientes. El primero ubicado en la escena "Camino de Belén" de su Farsa:

Hoy parió la luz del día,

hoy parió.

Gran gasajo y alegría

siento yo.

(vv. 233-236)

Y el segundo al final del auto; con ritmo de pie quebrado, pero de versos heptasílabos agudos simétricos:

Huyhá, huyhó, pues nasció

el que el mundo redimió.

(vv. 453-455)

En fin, fórmulas estróficas variadísimas que recibirán el nombre genérico de villancico o de canción, cuya característica principal será la de poseer un estribillo interpretado por todos los personajes a cada copla entonada por un solista.

Pero, aunque minoritarios, también se cantan otros textos poéticos de métrica diferente. Desde las tradicionales canciones paralelísticas, tan antiguas, como ésta de Timoneda al comienzo de su Auto:

Para qué comía la primer casada, para qué comía la fruta vedada.

o las coplas de pie quebrado, al final del Auto del mismo Timoneda: 
Niño Jesús, no lloreys vos

anima mía, pues en nascer oy entre nos days alegría.

o las coplas reales (quintillas dobles), como en el anuncio del ángel de la Obra de B. Aparicio:

Pastores, no hayais temor:

habed gozo y alegría,

ques nacido el Redentor

de una virgen sin dolor

en Betlén, en la establía.

Ireis presto, sin tardanza,

a ver el niño precioso,

y poned vuestra esperanza

en él con gran confianza,

ques Dios misericordioso.

o seguidillas, como en el final del anónimo Auto del Nacimiento de 1652:

Vos solo sois valiente

por vida mía

pues estáis en las pajas

por darme vida.

o, incluso, romances como en el Diálogo del Nascimiento de Torres Naharro (caso único en los autos de Navidad documentado por nosotros):

GARRAPATA: Sus, pensemos

llegando qué cantaremos

que huelguen los que allí están.

BETISEO: Aquel romance diremos

"Triste estaba el padre Adán".

El romance, del que es autor el propio Torres, asonantado en -ía, tienen intención de cantarlo como final del auto, pero no lo cantan, porque lo sustituyen por un villancico dialogado:

Celorum vía nobilis est María

puesto que lo han cantado ya antes en la primera parte del Dialogo: 


\section{Triste estaba el padre Adán cinco mil años había, cuando supo que en Belén era parida María.}

Sin embargo, con toda la variedad de metros, algo tienen en común los textos cantados: el ser todos ellos ejemplos claros de una lírica popular y tradicional. Porque al margen de las características del "tono" y "estilo" literario seguidos por cada autor a lo largo de sus respectivos autos, llegado el momento de elegir un tipo de texto para las partes cantadas todos dejan el género dramático y eligen el lírico, y éste siempre en metros y formas poéticas populares. He aquí otro de los rasgos del tradicionalismo en que se mueven los autos de Navidad. Un ejemplo contundente: López Yanguas, uno de los más representativos del "estilo pastoril y castellano", compone su Égloga en coplas de arte mayor, pero llegado el momento final en que hay baile y canto reserva para él el villancico, el más popular metro de la lírica española.

No vamos a negar que muchos de los textos cantados rezuman una filosofía y erudición propias del refinado Renacimiento, pero tan bien diluidos en el marco general del villancico que con razón puede decirse en este punto que los autos de Navidad siguen siendo medievales. Lírica que, por otra parte, con sus características de sencillez, estilo pastoril, versatilidad y frescura permanente, se adapta perfectamente a los fines de la música.

\section{LOS INSTRUMENTOS}

Son muchísimos los instrumentos musicales que se citan en los autos de Navidad, la mayoría de tipo rústico y pastoril. Los más citados: la guitarra, el caramillo, el rabel, la churumbela o cherumbela, la gaita, las sonajas y el tamboril. Los menos: las chirimías, la bandurria, la flauta, los albogues, las zampoñas, silbatos, piçarras, cucharal y todo aquello que pueda hacer ruido. Pero los instrumentos musicales son posiblemente más materia literaria que instrumentos para la música contenida en los autos. Quiero decir que las citas a los instrumentos aparecen en los textos con mucha frecuencia fuera de los momentos musicales, como un signo identificador de los personajes que los utilizan y del ambiente rústico de los autos, con la misma función, por ejemplo, que utilizan el sayagués para sus disputas o presumen de sus vestimentas rudas o de sus orígenes villanos.

Papel principal, y repetidísimo, cumplen los instrumentos musicales como ofrenda al Niño. Como el Auto pastoril de Gil Vicente: 
Id vosotros al lugar

muy priesto, carillos míos,

y ño vamos tan vazíos:

traed algo que le dar,

y el rabé de Juan Xavato

y la gaita de Pravillos

y todos los caramillos

que hay en el hato

y para el niño un silvato.

(vv. 274-282)

O también como expresión exterior de la íntima alegría que ha producido en los pastores el anuncio de la Buena Nueva, como en las Coplas de Fray İ̃̃igo de Mendoza:

Mas ponte la tu çamarra, la que tienes de holgar, y tiempla bien tu guitarra, y yo con una guitarra començemos de bailar.

Y saquemos el cucharal y también mi caramillo, y llamemos a Pascual porque nunca vio atal, y a su hermano Minguillo... (estr. 129-130)

Son los menos los textos en los que los instrumentos musicales, bien por la acción referenciada, bien por las acotaciones del autor, suenan efectivamente. Lo que se hace, por ejemplo, en la Égloga de López Yanguas, en la que los distintos pastores van apareciendo en escena tocando cada uno de ellos un instrumento es una excepción en el uso general del teatro navideño:

Llega mingo Sabido tañendo la gaita y dice: Entra Gil Para tañendo una guitarra y dize: Aquí llega Benito tañendo un arrabé y llamando: Entra Pero Pança tañendo un tamboril y responde: etc.

A juzgar, pues, por lo que los textos muestran; los instrumentos musicales son más pretexto literario que elemento actuante en la escena. Pero cuesta creer que un teatro como el del "Officium Pastorum", $\tan$ realista, tan bullicioso, tan lleno de músicas y bailes llene sus 
textos de referencias a instrumentos concretos y no los utilice luego en los momentos para los que están hechos. Aunque de creer los testimonios de la época, el mísero bagaje con que las compañías de teatro deambulaban:

Sin más hato que un pellico, un laúd, una vihuela, una barba de zamarro, sin más oro ni más seda,

según dice Agustín de Rojas en su Viaje entretenido (1603), el cántico se haría a palo seco o con pobre acompañamiento. ${ }^{10} \mathrm{~A}$ más abundamiento, Vélez de Guevara no pone ningún reparo a que lo que los pastores utilicen cuando van hacia Belén con tanta alegría sea "el instrumento que huviere" (p. 95).

\section{LA DANZA}

Algo parecido a los instrumentos ocurre con la danza y el baile. Como acotación escénica o incluso como elemento a destacar en el resumen que se acostumbra a poner antes del texto propiamente dicho se citan innumerables veces; como en el Auto o Farsa de Lucas Fernández:

Entra Pedro Picado, y el Juan los lleva a Bethlén a adorar al Señor cantando, y bailando el villancico...

Pero ni se dice qué tipo de danza es la que se baila ni si, muchas veces, se llega efectivamente a bailar.

Los personajes alardean, sí, de ser los primeros y mejores bailarines:

En correr, saltar, luchar, nadie me llega al çapato. Pues en cantar y baylar, y en el caramillo tocar siempre so el mejor del hato.

(Lucas Fernández B, vv. 41-45)

10 Cit. por R. Pérez Sterra, art. cit., p. 265. 
y tienen a la danza por agasajo mejor y principal cuando discurren qué llevar como ofrenda al Niño:

Todos, pues, nos compongamos, para allá partir con priesa; pero, porque presto vamos, tomemos por la traviesa del cerro donde apriscamos. Y pues el cielo alegrando se está, según que demuestra, vámonos todos bailando; y tú, Antón, el baile adiestra, una canción entonando.

(J. Torres, Lucha alegórica, p. 76)

Pero en pocas ocasiones el texto y las acotaciones del autor son contundentes respecto a la realización efectiva del baile en escena. Una excepción muy notable, por lo explícita y por lo prolijo de su descripción, es la contenida en el final de la Égloga de López Yanguas, cuyo pasaje examinamos más atrás.

La danza concertada o el simple baile, como manifestación espontánea del júbilo de los pastores (ya se sabe la distinción neta que se hacía en esta época entre danza y baile), se concentran preferentemente en torno a tres escenas: a) Camino de Belén, una vez que los pastores deciden abandonar sus rebaños e ir a visitar al recién nacido; b) En los ofrecimientos ante el Portal, y c) Como despedida y final del auto. Pero, esporádicamente, aparecen también en otros momentos: al comienzo de la representación, como en la Danza de Suárez de Robles, o en la escena de la vela del ganado, como entretenimiento y ejercicio para combatir el tedio y el frío:

La zapoña y tamboril tocad, porque hemos de her una danza, y de essa suerte podrá ser que calentemos.

(Mira de Amescua, Auto, p. 124)

Que la danza llegó a ser elemento principalísimo en el teatro del Barroco - "la salsa de las comedias" se decía de ella-, tanto como número coreográfico incrustado dentro de la obra al servicio de la trama argumental, como número de entretenimiento del público asistente a los corrales en los entreactos de las comedias, o como fin de fiesta, nos lo demuestra la gran cantidad de danzas que se citan en los textos y las grandes polémicas surgidas por la moralidad o inde- 
cencia de las tales danzas durante los siglos XVI y XVII. Hasta 19 clases distintas cita Rodrigo Caro en sus Días geniales y lúdricos en el teatro del Barroco: el Pollo, el Hermano Bartolo, el Guineo, la Pesca Moza, la Japonesa, Juan Redondo, el Rastrojo, la Gorrona, la Pipiranda, el Guiriguirigay, el Villano, la Zapateta, el Polvillo, la Capona, el Santarén, el Pasacalles, el Canario, el Zapateado, el No me las ama nadie y "otra gran tropa de este género que los ministros de la ociosidad, músicos, poetas y representantes inventan cada día sin castigo"." $\mathrm{Y}$, además, las más famosas y populares de todas: la zarabanda y la chacona, que tantas condenas recibieron por parte de moralistas y teólogos: un baile (la zarabanda), al decir de alguien, "tan lascivo en las palabras, tan feo en los meneos, que basta para pegar fuego a las personas muy honestas". 12

Por todo ello, extraña que en los autos navideños, que empiezan, sí, en la Edad Media pero que llegan hasta el comienzo del siglo XVIII, se citen tan pocas veces por sus nombres respectivos. Lo general es leer en los autos sólo "Ahora los pastores bailan ante el Portal" o "Se hará una danza entre todos" o cosas así tan genéricas. Pero ¿qué clase de danzas son ésas? Dado el carácter de los autos, de los textos que se cantan y de los momentos en que se ubican dentro de la trama escénica hemos de suponer que serían danzas populares y bulliciosas o simples bailes, que eran expresión más espontánea y libre de la alegría colectiva.

Unos pocos nombres hemos podido entresacar de los textos examinados:

La chacota, citada dos veces por Gil Vicente en su Auto de la Sibila Casandra; la primera para la entrada de los personajes en escena ("Entran bailando un chacota", p. 50) y la segunda en la escena camino de Belén ("Vanse cantando y bailando una chacota y llegando al pesebre...", p. 65). Una duda cabe aquí: No sabemos si se trata de la específica chacona, baile famosísimo de los siglos XVI y XVII que se ejecutaba con acompañamiento de castañuelas y coplas, o de la genérica chacota, según el DRAE "bulla y alegría mezclada de chanzas y carcajadas con que se celebraba alguna cosa". Más parece lo primero aunque aparezca con variación léxica.

La folía, citada también por Gil Vicente en el mismo Auto de la Sibila como baile con el que entran en escena varios personajes a mitad de la obra ("Vase Salomón y vuelve en seguida con Isaías, Moisés y Abrahán, bailando los cuatro una folía y cantando la cantiga siguiente..." (p. 53).

11. Cit. por J. Hesse, Vida teatral en el Siglo de Oro, Madrid, Taurus, 1965, p. 96.

12 P. Mariana, Liber de spectaculis, B.A.E., XXX, 1950, p. 30. 
Y como mudanzas especiales:

El cruzado, citado por Mira de Amescua en su Auto del Nacimiento en el momento de la adoración y ofrecimientos al recién nacido:

-Regocijemos la fiesta.

¿Qué hacemos que no bailamos?

-Un cruzado concertar

podemos, que es lo mejor.

Y la reverencia, citada por Vélez de Guevara en su Auto del Nacimiento y por Suárez Robles en su Danza, como tipo de mudanza propia de los ofrecimientos en que cada pastor llegaba hasta el Niño bailando y ante él, haciendo una reverencia, le entregaba su don y regresaba al grupo. (Esta danza -el nombre al menos- pervive en algunas versiones de la pastorada leonesa con la misma función que en Vélez de Guevara).

$\mathrm{Y}$ nada más. Pocos nombres para actividad tan repetida y función $\tan$ destacada dentro del teatro navideño.

\section{LA MÚSICA}

¿Cómo era la música que se cantaba o la que acompañaba a las danzas del teatro navideño? Porque de haberse conservado habrá que buscarla en otras fuentes distintas a los propios autos. En ellos no están. Tenemos constancia histórica de que en algunos autores se daba la doble condición de poeta y músico (Encina, Lucas Fernández, Gil Vicente), por lo que en esos casos damos por supuesto una misma autoría. 13 Pero en los casos mayoritarios en los que el autor no era músico ide dónde tomaba éste la música? ¿Adaptaba una melodía preexistente o lo dejaba al libre albedrío de las compañías de teatro? Sabemos que a partir del XVI existían ya compañias "profesionales" de teatro que ofertaban su repertorio en el pueblo o ciudad donde querían representar y que llevaban entre su elenco un reducido número de músicos profesionales. Y también que para mediados del XVI existían ya varios Cancioneros musicales (el de la Colombina, el de Palacio, el de Upsala, el de la Catedral de Segovia, los Villanctcos y Canciones de Juan Vasquez) en los que se recogía un imponente

${ }^{13}$ Gil Vicente lo dice él mismo en su famosísimo "Muy graciosa es la doncella", perteneciente a su Auto de la Sibila: "Cantan la canción siguiente, que hizo el autor y a la cual él mismo puso música" (p. 67). Pero, por el contrario, Encina no lo es de la música del único villancico cantado de su teatro navideño pastoril, el que empieza "Gran gasajo siento" de su Egloga 2. 
repertorio de villancicos, canciones, serranillas, romances y otras formas poéticas-musicales populares y cortesanas de muy diversa temática, entre las que las pertenecientes al ciclo navideño no eran las menos numerosas (sobre todo en el de Upsala), aunque al decir ciclo navideño haya que entender englobados en él los infinitos villancicos de la literatura de la época, tanto los que tienen un carácter autónomo como los pertenecientes al teatro de Navidad.

Está por hacer aún la identificación de los textos cantados en el teatro navideño entre los repertorios de los Cancioneros musicales, por lo que no podemos asegurar que falten absolutamente. Absolutamente no, porque al menos están el villancico "Gran gasajo siento yo" de la Égloga II de Encina en el Cancionero Musical de la Catedral de Segovia ${ }^{14}$ y el villancico "Nora buena quedes, Menga" del Auto pastoril de Gil Vicente en el Cancionero de Palacio, "s aunque ambos con música anónima. Pero si no faltan absolutamente, y hasta tanto se haga esa investigación, sí parece que faltan en su gran mayoría. Los villancicos que aparecen en los Cancioneros son los de tipo autónomo, textos de autor o anónimos que formaban parte de sus respectivas producciones líricas, bien en colecciones de poesía lírica, bien como textos independientes.

Esta falta aparente de documentación de los textos teatrales navideños (son más de 70 los números musicales que hemos catalogado de entre los 24 autos estudiados) plantean varias alternativas:

a) Puesto que la música, a lo que parece, nunca se publicó en el cuerpo de sus textos correspondientes, acompañando al texto literario, es porque se publicó independientemente, en otro tipo de registro.

b) Que sólo alguno de esos textos musicales llegasen a formar parte de los grandes Cancioneros musicales conocidos hoy (como los villancicos de Encina y Gil Vicente antes citados), dándose la gran mayoría al olvido o por perdidos.

c) Que sólo los menos, de entre los textos que dicen estar musicados en los autos, hubiesen llegado a tener efectivamente música propia (bien fuese del propio autor o de otro músico anónimo) y que la norma general fuese que el autor de la comedia confiase en la improvisación de las compañías de teatro en el momento de la representación, bien utilizando una melodía preexistente, bien improvisando en el momento. Es muy ilustrativa, a este respecto, la acotación que Mira de Amescua pone en su Auto al comienzo de un canto

14 Cf. R. O. Jones y C. R. LeE en su edición de Poesta Lírica y Cancionero Musical de Juan del Encina, Madrid, Castalia, 1975, p. 369.

15. Cit. por ReBelo BonIto, "Um cántico greco-latino e Um texto musical de Gil Vicente", en Gazeta Musical, Lisboa, 1954, p. 25. 
colectivo de los pastores: Salen los pastores "cantando como quisiere(n)", dice Mira.

La falta de esas músicas particulares no nos impide, sin embargo, suponer cómo serían. A parte de las pocas conservadas, podemos juzgar, por analogía, con los otros villancicos y canciones del ciclo de Navidad contenidos en los Cancioneros y, además, más de cerca aún, por las indicaciones y comentarios que los propios autores ponen entre el texto y las acotaciones escénicas de los autos.

No son muchas éstas, es cierto, pero tan contundentes y precisas, tan coincidentes entre sí, que podemos creerlas uso común en todos los autores y obras. Lucas Fernández, uno de los pocos músicos y poetas reconocidos de entre los que escribieron autos de Navidad, acaba todas sus obras (tanto las religiosas como las profanas) con un villancico que dice se canta y "está puesto" en "canto de órgano". Esta indicación aparece en el prólogo-resumen de sus dos autos navideños:

$Y$ finalmente se van todos a le adorar cantando el villancico que en fin es escrito, en canto de órgano"

(L. Fernández, A, p. 165)

Y el Juan los lieva a Bethlém a adorar al Señor cantando y vaylando el villancico en fin escripto en canto de órgano"

(L. Fernández, B, p. 189)

Y lo vuelve a repetir en el interior del primero, después de conocer los pastores el anuncio del Ángel:

Aquí se han de fincar de rodillas todos quatro y cantar en canto de órgano:

Et homo factum est, et homo factum est; et homo factum est

(L. Fernández, A, p. 181)

El "canto de órgano", como modo de interpretación de los villancicos teatrales, vuelve a ser citado por López Yanguas en el momento final de su Egloga. Pero aquí el autor es mucho más explícito. Como ya vimos antes al comentar este interesantísimo pasaje final de Yanguas, el "canto de órgano" que se proponen hacer los pastores es un coro concertado de 4 voces: tenor, bajo, tiple y contralto, en donde no haya falta alguna ni tono mal dado.

Domina en la España de esa época un estilo musical que es el que debemos atribuir también al teatro navideño. Ese "çanto de órgano" no debe ser otro que la polifonía profana de marcado tipismo hispano en donde se combinan una inspiración popular y unas formas polifónicas cultas. Ese extraño maridaje entre unos elementos antiguos, medievales y autóctonos, y unos elementos nuevos, renacentistas y extranjerizantes, no es exclusivo de la música: se da en todas las manifestacio- 
nes culturales españolas de la época, especialmente en la literatura, haciendo del Renacimiento español un movimiento singular, característico y distinto a los demás Renacimientos europeos. La polifonía, que es una forma culta, se monta sobre un sentir y unos textos tradicionalizados por siglos de existencia, y el villancico, como forma estrófica eminentemente popular, heredera de la más antigua lírica tradicional española, se convierte en el armazón perfecto para los músicos. Polifonía que, en todo caso, ha de dejar entender con claridad el texto que se canta y no oscurecerlo. Los juegos de voces contrapunteadas se dan sólo -o con primacía- en los estribillos, por lo que al repetirse varias veces permiten el entendimiento del texto, y se deja para las coplas las voces llanas de los solistas, lo que permite una influencia directa emocional en el recitado y una monodia como forma de proyectar con claridad el texto al espectador. López Calo habla de la existencia de dos tipos de melodías en el teatro primitivo: "Para las obras escritas en latín se seguía el estilo antiguo, el renacentista de la polifonía (...), mientras que las en romance -pronto delimitadas a las celebraciones del Corpus, Navidad y otras pocas fiestas- eran en el estilo nuevo". 16

Así, la música se convirtió en un elemento más del carácter popular y tradicional del teatro de Navidad. Los autos, siendo representaciones paralitúrgicas que se celebraban en las iglesias y en torno a las celebraciones litúrgicas, fueron desde sus orígenes (en el tránsito del drama litúrgico en latín al auto religioso en castellano) manifestaciones del más amplio y profundo estilo popular. Todos los elementos de este teatro estarán al servicio de esta idea: los personajes, sus propios nombres, las acciones, los razonamientos teológicos subyacentes en el texto, la simplicidad de sus estructuras dramáticas, la repetición casi invariable de esquemas escénicos, el lenguaje, la música, todo. De ahí que la creación de una partitura musical original para cada auto, y aun para cada número musical dentro de cada auto, parezca contrapuesto con el espíritu general que gobernaba la tradición. Lo más probable parece ser el anonimato en la creación de esas músicas y, en todo caso, la adaptación de unas melodías a unos textos y a unos momentos escénicos concretos.

Porque el carácter popular de los autos de Navidad viene determinado por los propios autos, es evidente, pero también por el público a quien va dirigido. La función primera de la música dentro del teatro de "crear ambiente", "deleitar por medio del adorno", "dar sensación

16 "La música religiosa en el barroco español", en La música en el barroco, Universidad de Oviedo, 1977, p. 155. 
de abundancia", "cambiar el ritmo de la obra", etc. 17 se lograría en el teatro navideño con músicas bien asimilables por el auditorio, con contrapuntos sencillos que no oscureciesen el texto, con instrumentos rudimentarios y de gran "gritería", con alborozo desordenado: "Cantemos en grita", dice un pastor de López Yanguas (v. 449); "Pues debemos levantar / un cantar con que llevemos / y gran regolax ('jolgorio') llevemos", dice otro de Lucas Fernández B (vv. 525-528); "Cantemos a voz en grito", dicen todos los pastores de Gil Vicente (Auto pastoril, v. 290); etc. Una música que sale de bocas de personajes que dicen razones tan rudas como la de éste:

Yo, miafé, no cantaré, qu'estoy tan relleno de ajos que me ahogo con gargajos y echar habra ('habla, voz') ño podré.

(Lucas Fernández B, vv. 532-537)

Otra cosa es la funcionalidad de la música dentro de los autos. La música, los números musicales, a pesar de ser tan numerosos, no son narratológicamente imprescindibles en la trama dramática de los autos. Los números musicales aparecen insertos en el texto, en las escenas que hemos especificado, como pequeños núcleos independientes, con autosuficiencia estructural. Dejan de ser textos dramáticos para convertirse en líricos, con vida independiente dentro del todo. Podrían faltar sin romperse esa trama argumental y sin perder nada del mensaje final de "evangelio ejemplificado" que representan, pero no cabe duda que de faltar, los autos dejarían de ser lo que son.

Otra función bien distinta, además de lo señalado, es la que cumple la música en algunos autos navideños tardíos (del XVII), sin duda como prolongación de lo que ya es común en el teatro del Barroco: el de crear ambiente. No sabemos muy bien qué tipo de música era ésa, pero ahí está indicada en los textos en los momentos en que se requiere un tratamiento especial para el misterio que conllevan: como por ejemplo el anuncio del Ángel, o el descubrimiento del Portal, o la aparición de los Reyes Magos. El Ảngel aparece y desaparece de escena con música de chirimías (Mira de Amescua); los pastores caminan cantando y bailando hacia el Portal, pero al llegar a él otra música distinta (de chirimías en Mira de Amescua, con cánticos que "vienen de adentro" en Vélez de Guevara o con una genérica e

17 Vid. J. M. DfEz BoRQue, Sociedad y teatro en la España de Lope de Vega, Barcelona, Antoni Bosch, editor, 1978, pp. 268-297. 
indeterminada "música" en el Auto anónimo de 1652) los paraliza ante la visión sobrenatural que se ofrece ante ellos:

Van andando todos algunos pasos por el teatro y se descubre mui lejos entre unos ramos de laurel el Niño Jesús en la cuna con la Virgen y S. Josef y algunas luces. Música.

(Auto de Nacimiento (1652), p. 260)

Los reyes aparecen en el Auto de Godínez B precedidos de una música que "viene de dentro" para resaltar su majestad:

Tres Reyes que están de fiesta que oy fiesta de Reyes es.

Una tercera función aparece también en algunos autos del XVII, sobre todo en Mira de Amescua y Godínez: la de la música convertida en personaje. Personificación que actúa preparando y anunciando escenas especialmente significativas, que requieren diferenciarse de la monotonía del resto; personificación alegórica que anuncia lo sobrenatural:

Tocan chirimias y vase el Ángel y canta la Música al irse:

MUSICA: Serafines gozosos, cantad la humildad de María divina donde Dios está.

(Mira de Amescua, p. 113)

La diferencia de la música con función ambiental de la músicapersonaje está en que esta última es siempre canto de un texto lírico mientras que la primera es sólo instrumental. Pero las dos, repetimos, son incorporaciones añadidas tardíamente (no existen en los autos del $\mathrm{XV}$ y $\mathrm{XVI}$ ), sin que excluyan ni mengüen la función principal de elemento estructural que la música tiene también en los autos del XVIL.

\section{LA MÚSICA EN LOS AUTOS DE NAVIDAD DE TRADICION ORAL}

La pervivencia hasta la actualidad, por vía de la tradición oral, de unos autos de Navidad, de parentesco indudable con los autos de los siglos XV, XVI y XVII, tiene una importancia singular porque permite deducir similares comportamientos y funcionalidades. De la relación 
entre ambos, hablamos ya en nuestro libro La pastorada leonesa: Una pervipencia del teatro medieval. ${ }^{18} \mathrm{Y}$ no porque los anónimos de hoy deriven de los de autor de los siglos XV o XVI, sino porque ambos, los de antes y los de ahora, forman parte de una misma tradición con un origen común muy remoto, que hay que situar probablemente en el siglo XIII, con el nacimiento de una tradición oral que suplantaría a la tradición eclesiástica culta de los dramas litúrgicos escritos en latín.

La distribución de las partes cantadas alrededor de unas determinadas escenas, que hemos observado en los autos medievales y renacentistas, la vemos reproducida fielmente en los autos leoneses modernos: la misma distribución escénica, la mayoría de los mismos instrumentos musicales (la cultura material pastoril no ha cambiado apenas), la misma preferencia por la danza alrededor de los ofrecimientos, los mismos y unánimes villancicos finales cantados, los mismos modelos estróficos para los textos cantados, la misma naturaleza lírica de los textos cantados frente a los textos dramáticos que se representan, el mismo valor funcional de la música dentro del auto.

Un texto tradicional, sea literario o musical, evoluciona y cambia adaptándose en cada momento al momento en que se reproduce, pero conserva una sustancia que le hace seguir siendo el mismo, diferenciado e identificable frente al resto. $Y$ no es precisamente la melodía lo más perdurable de entre los elementos de la música sino, al contrario, lo más mudable, por lo que habrá que fijarse en otros aspectos para identificar especímenes con largo tiempo rodando en la tradición: por ejemplo en las estructuras rítmicas, como ha puesto de manifiesto $\mathrm{L}$. Siemens a propósito de un número musical de la pastorada. ${ }^{19}$ Pues bien, atendiendo a estos aspectos, puede decirse que algunos ejemplos musicales de las pastoradas (como las de otras tradiciones teatrales llegadas hasta hoy y de origen medieval: El Misterio de Elche, los autos de Reyes, de entre los más famosos), poseen una sustancia musical de tan venerable antigüedad que les hace contemporáneos, si no anteriores, a los autos de autor conocido de los siglos XV y XVI. ${ }^{20}$

18 Madrid, SEM, 1982.

19 "A propósito de dos nuevas versiones del n. 6 de la Pastorada", en Rev. Musicologia, VI, 1983, pp. $491-495$.

20 Cf. L. Siemens, "Las partes musicales de la Pastorada", en La pastorada leonesa, pp. 285-326. Para el Misterio de Elche cf. el estudio del P. Samuel RuBio sobre la polifonía: "La música del Misterio de Elche", en Tesoro Sacro-Musical, n.॰ 5, 1965, pp. 61-71; y el de Ismael FerNANDEZ DE LA CUESTA sobre la monodía: "Los cantos monódicos en el Misterio de Elche", en Revista de Musicologia, n.o 4, 1981, pp. 41-49. 


\section{CONCLUSIONES}

El teatro religioso en general, y el del ciclo de Navidad en particular, representa una obra "menor" en comparación a la producción dramática que se produjo en España en el Renacimiento y en el Barroco. Obra menor por los propios límites de los textos y por los nombres que figuran como autores de los mismos (no todos, sin embargo, son autores de segunda importancia o desconocidos del todo; los hay también de primer rango). Pero este teatro representa una línea totalmente española, definidora de una forma literaria que se ha manifestado la más duradera en la historia del teatro español. Desde ser la primera manifestación dramática en lengua castellana en los oscuros años de la Edad Media, y origen del teatro todo, llegó a su época de mayor esplendor en los siglos XVI y XVII y ha logrado pervivir hasta hoy, por medio de la tradición oral, en múltiples expresiones y variedades.

Pero chasta qué punto el comportamiento de la música en el teatro de Navidad es extensible al teatro en general en la época en la que los autos de Navidad estuvieron vigentes?

Estamos analizando un período demasiado extenso (más de dos siglos) para poder hablar de comportamientos monolíticos y estancos. $Y$ sin embargo el teatro religioso del "Officium Pastorum" tiene ese carácter. Se trata de un teatro que hunde sus raíces en la Edad Media y llega hasta el Barroco (hasta hoy en la tradición oral) sin evolución sustancial. La tiene, claro, en aspectos exteriores a la propia estructura dramática: cierta complicación de la escenografía, mayor número de personajes, lenguaje más evolucionado, mayor desarrollo de las situaciones particulares, sensibilidad más artística, etc. Pero la línea que inspira la "filosofía" de los autos permanece inalterable. Es eso: un teatro tradicional, monolítico, repetitivo. Ni siquiera los autores de más nombre, que significaron cada uno de ellos pasos importantes adelante en la historia del teatro español (Encina, Gil Vicente, Torres Naharro, Sánchez de Badajoz, etc.) aportaron nada nuevo y significativo en el teatro religioso de Navidad. Sí lo hicieron en el teatro profano e incluso en otros ciclos del teatro religioso, pero en los del "Officium Pastorum" básicamente siguen reproduciendo los mismos esquemas medievales.

Así pues, el teatro navideño vive al margen y a otro nivel que el teatro profano. Y es así porque cumple una función bien distinta de aquél. Se ha hablado siempre del carácter litúrgico primero y paralitúrgico después del antiguo teatro castellano; una especie de "sermón representado" sobre el mensaje y sentido de determinadas festivida- 
des religiosas. $\mathrm{Y}$ ese carácter conmemorativo permanece inalterable a lo largo de los siglos. No podía ser de otra forma cuando en él se predican las verdades y dogmas de la fe. Existen para ser representados en unos días muy concretos y en unos lugares determinados, no en cualquiera ni en cualquier momento. No creemos que el gusto cortesano de fines del $\mathrm{xV}$ de hacer representar los autos religiosos dentro de los palacios y en escenarios no especialmente dedicados al culto (tenemos constancia de las representaciones navideñas que desde 1460 se celebraban en el palacio jienense del Condestable Lucas de Iranzo, y de las que en 1492 Juan del Encina representó en el palacio de los Duques de Alba) sea la norma general. Al contrario, el teatro religioso tiene en las iglesias y catedrales su escenario más natural. Célebre es el decreto alfonsí de Las Partidas condenando las representaciones en los templos, sobre todo cuando en ellas intervenían clérigos y en ellas se producían irreverencias y desmanes; especialmente importantes son las Memorias del canónigo Felipe Fernández Vallejo sobre las representaciones teatrales en la Catedral de Toledo desde el siglo xm. ${ }^{21} \mathrm{Y}$ al ámbito de las iglesias y a su escenario disponible se refieren una y otra vez los autores en sus acotaciones y en las mismas referencias de los textos. Ese carácter paralitúrgico llegó hasta principios del XVIII en que fueron definitivamente prohibidas las representaciones en las iglesias. La prohibición hizo que se acabase la creación de tanto auto de Navidad ( $\mathrm{C}$ había acabado antes, a fines del XVII, por sí mismo?), pero las representaciones siguieron y han llegado milagrosamente hasta hoy en las aldeas más pequeñas y apartadas de Castilla y León conservando inalterable ese espiritu "paralitúrgico". "Los autos -dice Wardropper, uno de los mejores conocedores del teatro religioso español- son una fusión de los sentimientos artísticos y religiosos del pueblo como la liturgia misma." 22

Pues esas características determinan también que la música tenga en el teatro de Navidad un comportamiento singular. Al hacer una visión general sobre la presencia de la música en este teatro se advierten tres conclusiones:

a) La sorprendente gran abundancia de intervenciones musicales.

b) Una ubicación de esas intervenciones a lo largo de las obras no arbitraria, sino determinada a unas escenas muy concretas que se repiten según un modelo común, y

c) La muy diferente presencia cuantitativa que tiene la música en unos y otros autores; así, frente a unos que escriben verdaderas églogas musicales hay otros que se limitan a un simple villancico final.

21 Cf. F. LAzaro Carreter, Teatro medieval, Madrid, Castalia, 19814, pp. 26-31.

22 Introducción al teatro religioso del Siglo de Oro, Madrid, Anaya, 1967, p. 87. 
Pero a pesar de tantos textos cantados y tanta presencia de la música en los autos, desconocemos propiamente cómo era. Falta confirmar el paradero de esas músicas y es necesario rastrear los Cancioneros en su búsqueda. A tal fin, adjuntamos a continuación, como apéndice, un índice de primeros versos de los textos cantados de los 24 autos que nos han servido para este estudio. Y falta también por averiguar si el carácter de la música que suponemos para los autos (la polifonía profana de corte populista) evoluciona al ritmo de las épocas sucesivas en que se produce o si permanece inalterable conforme a lo que hacen el texto literario y los esquemas dramáticos.

ÍNDICE DE PRIMEROS VERSOS DE TEXTOS CANTADOS EN EL TEATRO DEL CICLO DEL "OFFICIUM PASTORUM"

Aburramos la majada / y todos con deboción: Gil Vicente, vv. 283-4 Adiós, pastores y todos / el Gloria in excelsis Deo: Godínez B, p. 110 iAh, Gil Pata! ¿Qué es, carillo? / iPero Pança!: López Yanguas, vv. 480-1 iAh, pastor, / que es nacido el Redemptor. Gil Vicente, vv. 254-5

A la vela, vela, vela, buen pastor, / que por más que veles morirás de amor: Comedia, vv. 1197-8

Albricias, albricias, / que el amor concierta: Mira Amescua, p. 125

Allá en Belén / nace nuestro Dios: Suárez Robles, vv. 292-3

A maitines tocan las campanillas / como nace a maitines el Sol del día: Vélez Guevara, p. 82

Ave María hermosa, / de gracia toda cumplida: López Ranjel, vv. 25-6

Bras, Antọn y Gil, / y Pascual, y Bato: Mira Amescua, 124

Callaos, Señor / Nuestro Redentor: Gómez Manrique, vv. 161-2

Clara estaba la noche / más que el sole: B. Aparicio, p. 236

Celorum vía / nobilis est María: Torres Naharro, p. 383

Contentamientos de amor, / io quan caros que costais!: Comedia, vv. $920-1$

Chequito nos es nascido, / buen estrena, buen estrena: López Ranjel, vv. $110-1$

-Dezid, los pastores, / qué venís de ver: Lucas Fernández B, vv. 586-7 Dormid, mi Dios, a sabor / pues que duerme el pecador: Comedia, vv. $1374-5$

¿D'o venis, reina del cielo, / remedio de nuestra vida?: B. Aparicio, p. 244-5 
El Niño que nacido ha, / si está por acá: Comedia, vv. 1317-8

El pastor que tiene amores / quando a su ganado va: Comedia, vv. 468-9

Esclavo soy, pero cuyo / esso no lo diré yo: Comedia, vv. 956-7

Esta es embaxada, / muy grande entre las mayores: Fernando Díaz, vv. $113-4$

Esta novia se lleva la flor, / que las otras no: A. Castilla, p. 339

Este novio se lleva la flor, / que los otros no: A. Castilla, p. 340

Esta sí que es noche buena, / en que nace el Niño Dios: Mira Amescua, p. 127

Et homo factum est: Lucas Fernández A, v. 460

Fe en amor ya no se usa / y aunque a mí no se guardó: Comedia, vv. 542-3

Gloria a Dios en las alturas / demos como a Rey del cielo: Suárez Robles, vv. 51-2

Gloria a Dios en las alturas / y paz al hombre en la tierra: Mira Amescua, p. 125

Gloria in excelsis Deo / e na terra paz á gente: B. Dias, p. 190

Gran deporte y gran conorte / devemos todos tener: Lucas Fernández

B, vv. 541-2

Gran gasajo siento yo. / iHuy ho!: Encina A, vv. 181-2

Grullas, si vais allá, / acordaos de volver acá: B. Aparicio, p. 233

iHola, hau, carillos! / Pues a Dios tenemos: J. Torres, p. 77

Hoy parió la luz del día, / hoy parió: López Ranjel, vv. 233-4

Huyhá, huyho', pues nasció / el que el mundo redimió: López Ranjel, vv. $453-4$

Los pastores de Belén / con regocijo y amor: Godínez B, p. 107 Luchaban Dios y un pastor / en lo más alto del cielo: Comedia, vv. 1239-40

Menga Gil me quita el sueño / que ño duermo: Gil Vicente, vv. 20-1

Niño Jesús, no lloréis vos, / ánima mía: Timoneda, p. 226

Niño que del cielo baxas, / a mi remedio has baxado: Vélez Guevara, p. 85

No lloréis, mi Niño, / no lloréis, mi Dios: Comedia, vv. 1416-7

iNorabuena quedes, Mena! / iA la fe, que Dios mantenga!: Gil Vicente, vv. $329-30$

iOh pobrecillos pastores, / todo el mundo alegre sea: Fr. I. Mendoza, estr. 133 
iOh quién con vos encontrara, / Virgen, bien de nuestro bien!: B. Aparicio, p. 246

Ojuelos graciosos / que os estáis rriyendo, rriyendo: Comedia, vv. 188-9

O qué linda pradería, / qué prado para hazer fiestas: B. Dias, p. 151

Para qué comía / la primer casada: Timoneda, p. 222

Pasados contentamientos, / ¿qué queréis?: Comedia, vv. 1152-3

Pastora que en su cuidado / trahe rretratado un pastor: Comedia, vv. $353-4$

Pastores, dejad la sierra; / venid, veréis un zagal: Comedia, vv. 212-3

Pastores, lindos, serenos / ca dónde venís, decí?: Suárez Robles, vv. 127-8

Pastores, no hayáis temor: / habed gozo y alegría: B. Aparicio, p. 236

Por la mar iban mis ojos / quiérome ir con ellos, no vayan solos: Comedia, vv. 718-9

Pues habemos adorado / a este santo mozuelo: B. Aparicio, p. 243

Pues vimos la madre entera / la turulú, turulá, turulera: López Ranjel, vv. 474-5

¿Quién habrá que no se asombre / viendo lo que vemos nos?: Comedia, vv. 147-8

Quitaos allá, desengaños, / no vengáis: Comedia, vv. 1072-3

¿Quándo te verán mis ojos, / pastora de amor vencida?: Comedia, vv. $641-2$

Sea bien venida / la bella María: Mira Amescua, p. 116

Serafines gozosos, / cantad la humildad: Mira Amescua, p. 113

Si del mirar naze, / ver y desear, ver y desear: Comedia, vv. 37-8

Si el pan se me acaba, / cqué comeré?: B. Aparicio, p. 234

Tanto bien como ay en mi bien / y tanto bien: Comedia, vv. 1516-7

Tiempo es ya que se destierre / la guerra de nuestra guerra: Fernando Díaz, vv. 355-6

Tomemos todos pastores / gran gasajo y alegría: B. Dias, p. 193

Triste estaba el padre Adán / cinco mil años había: Torres Naharro, p. 372

Una serranica / su mano me diera : Comedia, vv. 824-5

Vamos todos a Bèlén / con amores: B. Aparicio, p. 241

Venga norabuena / a ver a Isabel: Mira Amescua, p. 115

Verbum caro factum est / alleluya: Lucas Fernández A, vv. 601-2

Vos solo sois valiente / por vida mía: Auto Nacimiento, vv. 313.4

Ya es ganada paz entera / oxalá la gloria fuera: Timoneda, p. 227

Yo soy la que alegra el mundo / este día: B. Aparicio, p. 237-8 


\section{BIBLIOGRAFIA DE OBRAS CITADAS}

Aparicio, Bartolomé: "Obra del Santísimo Naçimiento de nuestro Salvador Jesucristo, llamada de "El Pecador" (1611), en Gallardo: Ensayo de una biblioteca española de libros raros y curiosos, t. I, ed. Facsímil, Madrid, Gredos, 1968, pp. 221-245.

-: "Auto de la huida a Egipto" (principios s. XVI), en Dramas litúrgicos, siglo XVI, ed. de Jaime de Moll, Madrid, Taurus, Col. Temas de España, 1968, pp. 78-94.

- "Auto de Nacimiento de Christo Nuestro Redentor" (1652), en Revue Hispanique, ed. de E. D. Roberts, t. LXXVI, 1929, pp. 346-359.

- : "Auto de los Reyes Magos" (fines s, XII), en Teatro medieval, ed. de F. Lázaro Carreter, Madrid, Castalia, 3.a ed. 1970, pp. 97-196.

CAstilla, Antonio de: "Auto sacramental al nacimiento del Hijo de Dios" (mitad s. XvI), en Autos, loas y entremeses al nacimiento de Cristo, fols. 339-353, Madrid, 1675.

"Comedia a lo pastoril para la noche de Navidad" (1550), en Revue Hispanique, ed. de J. P. W. Crawford, t. XXIV, núm. 66, New York-París, 1911, pp. 497-541.

DiAS, Baltasar: "Auto de nascimiento de Nosso Señor Jesu Christo" (1665), en Autos e Trovas de Baltasar Dias, ed. de Alberto F. Gómes, Funchal, 1961, pp. 151-215.

DiAZ, Fernando: "Farsa nuevamente trobada por ___ " (1554), en Teatro español del siglo XVI, ed. de U. Cronan, Madrid, 1913, pp. 319-332.

Encina A: ENCINA, Juan del: "Égloga del Nacimiento" (que empieza "Dios mantenga" (1492), en Obras dramáticas, I (Cancionero de 1496), ed. de Rosalie Gimeno, Madrid, Istmo, 1975, pp. 103-120.

Encina B: ENCINA, Juan del: "Égloga del Nacimiento" (que empieza "Miguellejo, ven acá") (1498), en Teatro (Segunda producción dramática), ed. de Rosalie Gimeno, Madrid, Alhambra, 1977, pp. 109-137.

L. Fernández A: FernÁndez, Lucas: "Égloga o Farsa del Nacimiento" (1500), y

L. Fernández B: Fernandez, Lucas: "Auto o Farsa del nacimiento" (1500), en Farsas y Églogas, ed. de M. Josefa Canellada, Madrid, Castalia, 1976, pp. 165-187 y 189-210, respectivamente.

Godínez A: GodtNez, Felipe: "Auto del nacimiento de Cristo" (1588-1639), y

Godínez B: Godinez, Felipe: "Auto del nacimiento de Cristo" (1588-1639), en Autos, loas y entremeses al nacimiento de Cristo, Madrid, 1675, fols. 88-99 y 100-111, respectivamente.

GOMEZ Manrioue: "Representación del Nacimiento de Nuestro Señor" (entre 1467-1481), en Teatro medieval, ed. F. Lázaro Carreter, Madrid, Castalia, 3. ${ }^{a}$ ed., 1970, pp. 107-115.

LOPEZ RANJEL, Pero: "Farça a honor y reverencia del glorioso Nascimiento de Nuestro Redenptor Jesu Christo y de la Virgen gloriosa, madre suya" (1530), en Dramas litúrgicos, siglo XVI, ed. de Jaime de Moll, Madrid, Taurus, 1969, pp. 27-50.

LOPEZ Yanguas, Fernán: "Égloga nuevamente trobada en loor de la Natividad de nuestro Señor" (1518), en Obras Dramáticas, ed. de F. González Ollé, Madrid, Clásicos Castellanos, 1967, pp. 3-30.

MendozA, Fr. Iñigo de: "Las Coplas de Vita Christi" (1482), en Cancionero, ed. de J. Rodríguez Puértolas, Clásicos Castellanos, Madrid, 1968.

MiRa de AMESCUA, Antonio: "Auto del nacimiento de Nuestro Señor" (1616-1620), en Autos, loas y entremeses al Nacimiento de Cristo, Madrid, 1675, fols. 111-128.

SANCheZ DE BAdajoz, Diego: "Farsa de la Natividad" (1525-1547), en Farsas, ed. de J. M. Díez Borque, Madrid, Cátedra, 1978.

SuARez de Robles, Pedro: "Danza del Santísimo Nacimiento de Nuestro Señor Jesu Christo, al modo pastoril" (1561), en Dramas liturgicos, siglo XVI, ed. de Jaime Moll, Madrid, Taurus, 1968, pp. 51-64. 
TImoneda, Juan de: "Aucto del Nascimiento" (2." mitad s. XVI), en Rev. Razón y Fe, ed. por la Sociedad de Bibliófilos Valencianos, XLVIIL, 1917, pp. 219-227.

TORRES, Jaime: "Lucha alegórica para la noche de la Natividad de Cristo, Nuestro Señor" (1578), en Dramas litúrgicos; siglo XVI, ed. de Jaime Moll, Madrid, Taurus, 1968, pp. 65-77.

Torres Naharro, B: "Diálogo del Nascimiento" (1512), en Propaladia, II, ed. de Menéndez Pelayo, Col. Libros de Antaño, X, Madrid, 1900, pp. 347-385.

Velez De GuevarA, Luis: "Auto del Nacimiento de Cristo" (1625), en Autos, loas y entremeses al nacimiento de Cristo, Madrid, 1675, fols. 82-88.

VICENTE, Gil: "Auto de la Sibila Casandra" (1513), en Obras Dramáticas, ed. de Thomas R. Hart, Madrid, Clásicos Castellanos, 2.a ed., Madrid, 1968, pp. 43-68.

- "Auto pastoril castellano" (1502-1510), en Obras Dramáticas Castellanas, ibid, pp. 7-24.

\section{COLOQUIO}

M. QUerol: A propósito de la música en el Teatro de Navidad y sobre la presencia de villancicos en la Liturgia me gustaría puntualizar lo siguiente: Sólo en la tragicomedia de Gil Vicente, Cortes de Júpiter, hay una docena de intervenciones musicales; entre ellas está el villancico "Nunca fué pena mayor", que es el más conocido de toda la historia, pues está hasta en las antologías extranjeras y en el número 1 del Cancionero de Palacio; y está también "Doncella por cuyo amor" y "Gentil dama valerosa", ambas en el Cancionero de Palacio. El director de compañía Miguel Navarro sacó "a la vista de los espectadores la música que antes cantaban detrás". Aquello constituyó una novedad, como había de constituirlo tres siglos más tarde la ocultación de la orquesta en el teatro wagneriano de Bayreuth. Después viene Calderón y los hace cantar en "off", fuera de escena. Respecto a Juan del Encina, en ocasión del centenario tomé unas notas, después de leerme todas las églogas, y hay dos cosas que quisiera observar como orientación. Uno lee una égloga de Juan del Encina y se encuentra que pone dos veces fin. El primer fin se refiere a toda la égloga y el segundo al final del villancico. Quisiera llamar la atención sobre la última obra de Plácido y Victoriano que se representó en la Corte del Papa León X. El argumento literario en sí tiene auténticos visos de ópera, a diferencia de todas las otras églogas. Hay un villancico en medio de la obra. Después viene la famosa vigilia de la "Enamorada muerta" que es un oficio de difuntos y comprende el Invitatorium, Psalmum, Psalmum, Psalmum, Requiem aeternam, Lección 1, 2, 3, Oración y Fin. Pone la primera palabra latina de cada parte del oficio de difuntos y glosa. Después continúa con la oración de Victoriano a Venus y los versos, y aquí acaba la representación, dice textualmente el libro, con una danza. Estos villancicos no están puestos porque sí. En los de Juan del Encina el texto está íntimamente ligado y es el final de todo lo que se ha representado hablando. Así que forman parte sustancial de la representación. No es una cosa que se pega.

D. BECKER: En cuanto a la égloga primera y segunda de Juan del Encina, parece que se da realmente dentro de maitines y no en la Iglesia, sino en la sala donde estaban los duques. Oyendo maitines prorrumpen los pastores y vienen a decir dos cosas: Primero una especie de égloga-introito donde se ofrecen las églogas y se anuncian las cien coplas que debe dar Juan del Encina a los duques como muestra de su vinculación reciente a 
la casa de Alba. Luego la segunda égloga, que es más del tipo del "officium pastorum". Los Duques, pues, oyen maitines en una sala y no en una iglesia. Pregunto: Los pocos villancicos que hay, ¿no será porque esta parte se enmarca como diálogo teatral hablado, dentro de un marco que ya es musical de por sí, que es el marco de los maitines, y que entonces esta parte se sustituye por una de las lecciones y termina con la música para enlazar con el final de maitines? Entonces reanuda, gracias al villancico, con la parte musical. De ahí se explicaría que con las dos primeras églogas, que son cortísimas, no daría lugar a más música. Mientras que lo de Lucas Fernández, que es teatro aparte, tiene que poner más música para lograr un equilibrio entre lo hablado y lo cantado. En cuanto a la égloga a la que le falta el villancico: Efectivamente, falta un villancico del tipo "Pastores vamos a Belén" y que se podría explicar de otra forma. Que todas las églogas anteriores las recoge el propio Juan del Encina, mientras que a partir de esta égloga aparece en otras copias que él no tuvo el cuidado de editar, y alli se pierde un villancico. Otros se recuperan después de las demás églogas. Pueden ser de él mismo o de otro que haya tenido más cuidado. Lo que pasa es que no tenemos los villancicos musicales de las últimas églogas, a excepción de uno que es el único que no tiene nada que ver con la égloga. Es cuando cantan "Ojos garzos a la niña", que no es lo que se esperaba al final.

M. TRAPERO: Sobre la primera cuestión: La escenificación, la ubicación y representación de las obras de Navidad. Efectivamente, a finales del siglo Xv parece que hubo una moda de representar los autos fuera de las iglesias, y es lo que se ha llamado el teatro cortesano. Eso ocurre no solamente en el caso de Juan del Encina, que él mismo lo dice, sino que a partir de 1460 , por ejemplo, se celebraban en el palacio del Condestable Lucas de Iranzo todas las representaciones de Navidad. Pero yo pienso que ésa es una moda pasajera y minoritaria. Los autos de Navidad nacieron para ser representados en la iglesia como sermón escenificado, que es la función que tenian, y no necesariamente en maitines.

M. QUEROL: En la sexta égloga se canta el villancico "Hoy comamos y bebamos" y en la séptima "Repastemos el ganado, hurriallá". En cuanto a si podía cantarse el villancico en maitines: No aparece hasta muy finales del siglo XVI el que un villancico sustituya a un responsorio de maitines. Pero en el siglo xvir los sustituye a todos, incluido la Kalenda. y desaparecen prácticamente los responsorios.

D. BECKER: En cuanto al oficio de difuntos, parece ser que es una parodia, pero también parece ser una parodia de la muerte y pasión de Jesucristo. En realidad Plácido muere un Viernes Santo y resucita el domingo de Pascua.

L. SIEMENS: Respecto a la introducción del villancico como sustituto del responsorio, está demostrado por López-Calo que fue el confesor de la Reina Católica, Fray Hernando de Mendoza, siendo arzobispo de Granada, el primero que hizo esta sustitución, muy a comienzos del siglo XVI. Lo que pasa es que eso ocasionó tales controversias entre la jerarquía eclesiástica que no se sancionó hasta después del Concilio de Trento, que dio el visto bueno tácitamente a esta costumbre.

D. Preciado: Un dato curioso de la sustitución del responsorio por el villancico y de la afición del pueblo español a los villancicos es el hecho histórico de que la sublevación de los moriscos en las Alpujarras se hizo la noche de Navidad, cuando los cristianos estaban gustosos oyendo los villancicos en las iglesias.

X. M. CARREIRA: Está claro que si fue tan bien aceptada la iniciativa granadina es porque habia una tendencia social hacia ella. 
